\title{
Emergent transformation games: exploring social innovation agency and activation through the case of the Belgian electricity blackout threat
}

\author{
Bonno Pel $^{1}$, Grégoire Wallenborn ${ }^{1}$ and $\underline{\text { Tom Bauler }}^{1}$
}

\begin{abstract}
The persistence of current societal problems has given rise to a quest for transformative social innovations. As social innovation actors seek to become change makers, it has been suggested that they need to play into impactful macrodevelopments or "game-changers". Here, we aim to deepen the understanding of the social innovation agency in these transformation games. We analyze assumptions about the game metaphor, invoking insights from actor-network theory. The very emergence of transformation games is identified as a crucial but easily overlooked issue. As explored through the recent electricity blackout threat in Belgium, some current transformation games are populated with largely passive players. This illustrative case demonstrates that socially innovative agency cannot be presupposed. In some transformation games, the crucial game-changing effect is to start the game by activating the players.
\end{abstract}

Key Words: actor network theory; electricity grid; enrolment; game-changers; social innovation; transformation

\section{INTRODUCTION: CHANGING THE GAME THROUGH SOCIAL INNOVATION?}

As is increasingly becoming voiced in industrialized societies, current modes of production and consumption continue to overstep the carrying capacity of the planet. The intertwinement of social and ecological systems is increasingly problematized with the recurrent calls for recognition of the anthropocene age. Arguably, strong sustainability requires various structural system transitions in mobility, energy, housing, and agricultural practices (Grin et al. 2010). Meanwhile, calls for structural transformative change in social and ecological systems are further reinforced by more traditional concerns about structural economic inequality, social exclusion, and exploitative modes of production.

In the collective imagination of progressive societies, societal transformations can be achieved either through avenues of political revolutions, state or institutional reforms, or technological breakthroughs. These vectors of change are typically combined in holistic approaches of system innovation, sustainability transitions, or adaptive management (Walker et al. 2004, Kemp et al. 2007, Grin et al. 2010, Smith and Stirling 2010). However, in recent years, there has also been a marked rise of interest in "social innovations" as vectors for societal change and transformation. Social innovation can roughly be understood as the introduction of novel social practices and relations (Mulgan 2007, Rammert 2010, Moore and Westley 2011, Schubert 2014, Howaldt et al. 2015). It is also often understood to rest on civil society action, grassroots activism, and otherwise self-organizing actors outside the dominant market-state institutions (Moulaert et al. 2013, Avelino et al. 2015). These relative outsiders are often considered to possess the requisite creativity and enterprising attitude to "change the game" (Mulgan 2007, Hubert 2010, ScottCato and Hillier 2010). Still, the consideration of structural power imbalances raises questions about the scope of such situated transformative agency and the processes through which transformative social innovation (TSI) emerges (Haxeltine et al. 2013, Cajaiba-Santana 2014).

Many social innovation initiatives demonstrate that they cannot bring about the transformations by themselves (Jørgensen et al.
2015, Wittmayer et al. 2015). Considering that such initiatives require favorable circumstances to have an effect, they often can be seen to play into certain high-impact macrodevelopments or systemic crises as windows of opportunity (Moore et al. 2012). Whether stemming from long waves of cyclical change or occurring as highly contextualized events, social innovation initiatives arguably need such game-changers to support their own attempts to change the game. Social innovation initiatives are assumed to be receptive to such macroevents and use them to construct more persuasive narratives of change (Jørgensen et al. 2015, Wittmayer et al. 2015), which help solidify and institutionalize their envisioned changes.

The game-changer metaphor is a persuasive sense-making device that conveys basic ideas about agency. Here, we critically consider the implicit assumptions that the metaphor carries: To what games do these game-changers refer? Which aspects of transformative social innovation processes does the metaphor help actors to understand? What social realities does it promote, and what aspects of transformative social innovation processes does it obscure? Invoking insights from actor-centered institutionalism and actornetwork theory (ANT), we develop a nonreductionist account of transformation games. A particularly decisive but easily overlooked issue seems to be the very emergence of transformation games. As will be illustrated through the case of the electricity blackout threat in Belgium, playful TSI agency cannot be presupposed. The case shows that sudden increased risk of infrastructure breakdown reminded passive players of their various social, technical, and ecological entanglements. It thus exemplifies how some transformation games need game-changers to get started and to become transformation games through the recruitment and activation of players.

We begin by explaining the concepts of TSI and game-changers and proposing a nonreductionist understanding of the associated transformation games. After a brief account of methods, the analysis of the Belgian energy blackout threat unpacks a process of apparent game-changing. Finally, we conclude with a discussion of recruitment and activation as crucial but easily neglected aspects of social innovation agency in transformation games. 


\section{GAME-CHANGERS IN TRANSFORMATIVE SOCIAL INNOVATION}

The concept of social innovation is gaining stability and visibility. Well-cited examples of social innovation are sharing schemes, cooperatives, social entrepreneurship, or various forms of ecocommunities. Generally, social innovation is understood to involve the purposive development of new social practices, roles, and relations (Mulgan 2007, Rammert 2010, Moore and Westley 2011, Schubert 2014, Howaldt et al. 2015). Especially in policy circles, social innovation is often characterized as "innovation that is social both in its ends as well as in its means" (Hubert 2010:9). Social innovation can be considered a class of innovations that is different from technical innovation (Franz et al. 2012, Schubert 2014) and a prolongation of socio-technical innovations. The emphasis given to social innovation might reflect a certain disenchantment with the technological reading given to human progress: social innovation is seen to respond to the threats raised or the needs that remain unmet by conventional technology-oriented innovation models and to unlock the petrified societal relations that are typically reproduced in technology-oriented innovation (Jessop et al. 2013). The socially innovative practices and relations are then considered as deliberate challenges to the existing institutional order in which civil society actors and "third-sector" organizations bring forward alternatives to dominant forms of market democracies (Unger 1987, Swyngedouw 2005, Nicholls and Murdock 2012, Moulaert et al. 2013).

As a counterpart and complement to technological innovation, social innovation can be considered as an important source of transformation in coupled socio-technical-ecological systems. Even if seldom discussed explicitly under that header, social innovation is acknowledged as an important aspect of sustainability transitions. Social innovation features particularly prominently in sustainability scenarios such as degrowth, downsizing, and decommodification. Transitions are shifts in coupled systems and require, by definition, a certain degree of social innovation (Moore and Westley 2011, Seyfang and Longhurst 2013). The particular importance of social innovations is further evidenced by the frequent critiques of technological fixes (Geels et al. 2012, Jensen et al. 2012, Verbong and Loorbach 2012) and the emphasis on power relations as a central transitionstheoretical analytical dimension (Smith and Stirling 2010, Avelino 2011, Geels 2014, Hess 2014). Moreover, the transformative potentials of social innovation are implicitly recognized in the somewhat latent social cracks in regime structures (Sheller 2012), shifts in cultural legitimacy (Verhees 2012), and the "critical niche" roles played by community initiatives (Smith et al. 2016). Finally, social innovation is social rather than individual by definition. It revolves around the mesocharacteristic of collectives, which has so evidently been neglected by marketoriented approaches to innovation.

For many reasons, either as complement to technological innovation or in its own right, social innovation can thus be accorded some potential to contribute to transformations. The provided examples also show how social innovation is often understood to revolve around civil society action and grassroots activism and to rest upon the self-organization of actors and the positioning of activities outside of the influence of dominant institutions (Moulaert et al. 2013, Avelino et al. 2015). These relative outsiders are often considered to develop the critical ideas (Smith et al. 2016) and the creative and enterprising capacities to change the game (Scott-Cato and Hillier 2010, Wittmayer et al. 2015). In this regard, it has been argued how social innovations may become transformative in dispersed, "rhizomic" fashion (Scott-Cato and Hillier 2010) or as informal activities that operate at the interstices of existing institutions (Nicholls and Murdock 2012). Still, many social innovation practices are not that transformative. First of all, social innovation initiatives may aim for local problem solving rather than for societal transformation. Second, there is the sobering circumstance that social innovation agents tend to be weakly positioned in relation to the social structures to transform. The rise of commercialized sharing schemes such as Uber and AirBnB exemplifies how social innovation is easily captured, eventually reproducing rather than transforming dominant societal structures (Pel and Bauler 2014). Likewise, it needs to be considered how the associated new governance arrangements easily introduce new forms of dominance and exclusion or hollow out the democratic governance capacities so dearly needed to regulate markets (Swyngedouw 2005). In generic terms (Cajaiba-Santana 2014), if social innovation initiatives are to realize their transformative potential and to exert influence on the "game", the social innovation field needs to part with its naïvely individualistic understandings of agency.

Regarding the apparent gap between microagency and macrotransformations, there is of course the transitionstheoretical wisdom that the pressures of landscape developments on existing regimes should be seized (Geels and Schot 2007, Grin et al. 2010), and that ongoing developments need to be modulated for favorable coevolution (Rip 2006). Likewise, transformation has often been theorized to require a certain triggering perturbation, crisis (Moore et al. 2014), or "wildcard event" (Walsh et al. 2015) for it to take off. It remains somewhat mysterious how such macrodevelopments could inform situated action, however (Jørgensen 2012). To advance comprehension beyond speculation, it is interesting to consider how social innovation actors do seem to make sense of their transformation situations through certain game-changers (Haxeltine et al. 2013).

This increasingly common term has been used to refer to a wide range of high-impact developments and events (see Tyfield et al. 2010). One can think of Internet 2.0, the rise of the BRICS countries (Brazil, Russia, India, China, and South Africa), or shale gas exploitation. In the context of social innovation, particularly salient game-changers have been observed to be climate change, structural unemployment, the approaching of peak oil, and the recent economic-financial crisis (Hopkins 2008, Klein 2014, Avelino et al. 2015, Jørgensen et al. 2015). Sudden crisis situations (e.g., the Fukushima reactor breakdowns, the food and mouth disease outbreak, and Hurricane Katrina) can similarly act as reminders of risk to society and the associated distribution of evils (Beck 1992).

Social innovation initiatives can be seen to refer to such gamechanging events and developments to understand their agency amid other broader societal forces. They invoke these gamechangers strategically to develop more persuasive narratives of change on alternative futures (Jørgensen et al. 2015, Wittmayer et al. 2015). Still, having sketched how this metaphorical term 
helps to make sense of the complex realities of socially innovative attempts at game-changing, it merits critical consideration what assumptions are introduced about the implied transformation games. In the following, we invoke an ANT perspective to question the seemingly self-evident categories of game-changing and quasi-autonomous game-changer events (see Jørgensen 2012). An ANT perspective typically suggests analyzing the assumptions about social innovation agency concealed in the notion of transformation games.

\section{FROM GAME-CHANGERS TO TRANSFORMATION GAMES}

The game-changer is a compelling sense-making device and a particularly persuasive metaphor. The rather individualistic, voluntaristic, social innovation striving toward changing the game is balanced with the acknowledgement of broader gamechanging that needs to facilitate or accompany it. Clearly the term does not constitute a clear set of concrete phenomena, however. As with any metaphor, the term is potentially misleading, but also holds the promise of conveying complex relations effectively (Chettiparamb 2006). The term, and the underlying understanding of transformation games, merits consideration for the relations it introduces between the domain of games (and game changes) on the one hand, and the domain of application, i.e., TSI, on the other.

The game metaphor expresses how social innovation is a phenomenon of multiple players and involves stakes and strategies. Moreover, it typically involves maneuvering and repositioning of actors, and processes in which players anticipate and adapt to each others' actions. The game metaphor usefully articulates this agonistic and playful, experimenting side of social innovation, and in particular, the strategic element of outsmarting opponents; that is, TSI tends to involve uphill struggles of subaltern, marginalized groups of actors. In this regard, the term game-changer brings attention to the rules of games, and especially the possibility of moving away from existing equilibria and accepted patterns of play. The metaphor acknowledges the reality of certain regime structures and societal rule sets, but also constitutes a liberating narrative in which the normal patterns can be altered through playful, creative, social innovators or through intervening game-changing developments.

Ostensibly, the game metaphor expresses a substantial amount of TSI complexity. It usefully shakes off idealistic views of TSI by providing a reminder of stakes, winners, and losers. Still, it seems to allude to a slightly naïve, if not deceptive, imagery of purposeful players and their capacities to strategize and successfully implement innovations. Insights from actor-centered institutionalism and ANT help to articulate this suspicion.

First, the typically game-theoretical attention to players' actual interests, prevailing rules, and likely outcomes easily obscures how these may change. Paradoxically, the focus on purposeful actors bypasses how purposes and goals are negotiated with other players and shaped by cultural norms. This is why game theory is better equipped to articulate game structure than game-changing; the groundbreaking work by Axelrod and Hamilton (1981) does not deny this. Most pertinent to TSI games is therefore Scharpf (1997), who developed a sociologically refined understanding of the games real actors play. His important conceptual enrichment is to situate players in complex, multiarena, multilevel games
(Scharpf 1997). This makes for a significantly more dynamic understanding of TSI games. Actors are acknowledged to differ in orientations and capabilities. Furthermore, Scharpf's games are populated by certain constellations of (collective) actors. In turn, these constellations can be played out in a variety of modes of interaction (i.e., cooperative games, voting games, or hierarchical games). Fundamental for this whole portrayal of affairs is that all the above game elements are seen to be shaped by the institutional setting (Scharpf 1997). By implication, gamechanging can take effect through changes on any of these interrelated game elements; this is the very underpinning of steering repertoires such as institutional design and network management (Koppenjan and Klijn 2004). Scharpf's actorcentered institutionalism thus articulates the duality of structure that is arguably an essential aspect of the games (Cajaiba-Santana 2014).

Scharpf (1997) provides a dynamic and typically nonreductionist portrayal of affairs. His game understanding is radicalized usefully by the relational ontology of ANT. The very notion of actor-network expresses similarly how players and games define each other recursively. A second refinement to the game imagery is the typical ANT critique of the anthropocentrism that the game metaphor invites. An ANT perspective reminds us that the very issues of TSI arise through concerns over social-ecological and social-economic couplings (Latour 2004). Law (2006), for example, shows how the foot and mouth disease outbreak crucially revolved around human players' difficulties in controling the nonhuman flows and mobilities created in the meat production system. Latour $(1992,2005)$ thus famously argued how nonhuman actors account for a significant part of the social order as silent players, without whom the current patterns of play would be inconceivable. Enrolling natural resources and technologies into their production systems, human players have delegated agency to those nonhuman actants. Human players thus become enmeshed in various chains of interdependency between human and nonhuman players. The equilibria that arise between these players (along technical, economical, practical, and ecological rationales) tend to be fragile. These solidarities are arguably crucial game elements. TSI games become dynamic once existing solidarities are found to be disappointing or unsustainable, and roles of particular players become contested.

Third, the players' multiple entwinements and solidarities with nonhuman players also unsettles the seemingly self-evident imagery of players who maneuver through a certain field. This field-player duality is an immediate suggestion of a game metaphor. However, in an ANT understanding, there is no sharp dividing line between acting players and a passive field (Bennett 2005). Agency is fundamentally distributed, and players and field define each other (Law and Hassard 1999). This view underscores how some players seek to stabilize certain network relations, e.g., to build large technical systems (Summerton 1994) or to create irreversible momentum (Hughes 1983), and thus delineate a field in which certain players lead and others are offside. Still, these delineations can be challenged and should not be treated as naturally given. In contrast to the chalk lines of football pitches or the hard delineations of chess boards, TSI games need to be treated as principally open-ended, continuous webs of solidarities. It is essential for the transformative games that the definition of the field, the system to be transformed, and the 
players that should be in or out of the arena, tend to be contested (Smith and Stirling 2010, Stirling 2011, Jørgensen 2012).

Fourth, these ANT considerations also question the presupposed purposiveness of the players and the suggested playfulness. The game-changer notion evokes an imagery of games in full swing and of creative players in the heat of the action, only to be suddenly disrupted and driven toward another pattern of play. However, the animated engagement with play is something to be explained (Bennett 2005). It has been problematized, for example, how communities can become adaptive co-managers rather than powerless spectators (Fabricius et al. 2007), and how historically emerged rigidities in society form crucial obstacles in current-day sustainability challenges (Scheffer and Westley 2007). Arguably, it is particularly in TSI games that these processes of historically emerged passivity, and of becoming involved, are pertinent. After all, social innovation can be read as a challenge to technologyoriented, consumer-catering innovation models and their associated petrified institutional structures. Because the delegation of play to nonhuman actants may become problematic, the transformation game may become about the inclusion, recruitment, and activation of sidelined players into the game.

\section{METHODS: ILLUSTRATIVE CASE OF AN EMERGENT TRANSFORMATION GAME}

Having outlined some of the particularities of transformation games and associated game-changing, we then developed a less reductionist understanding of these ideas. This approach crucially accounts for players' institutional settings, the social-technicalecological solidarities involved, the contested nature of the playing field, and the problematic involvement of players.

The proposed understanding of TSI games and associated gamechanging will be substantiated through an ANT perspective based on the illustrative case of the 2014-2015 Belgian electricity blackout threat. The revelatory function of a single case study is used to elicit particular aspects of the transformation game (Yin 2003). Drawing on media reports, interviews with actors in the Belgian energy sector (including small consumers), and observational data (Wallenborn and Gaye 2015, Wallenborn 2016), we describe how a sequence of events led to the threat of large-scale electricity blackouts in Belgium. Because this challenge to the electricity provision game seemed unsolvable through regular grid management strategies, alternative ideas about the playing field gained traction. Apart from the increased awareness of shared vulnerabilities, socially innovative ideas and practices gained prominence, such as energy cooperatives, microgrid solutions, experimentation with energy-saving lifestyles, and blackout parties. As a reason to question the normal course of play, the threat provided a potential game-changing event into which social innovation actors hoped to play. In terms of TSI, it disclosed and reasserted new solidarities (beyond the technical and economic ones) and recruited players for a transformation game in which they previously hardly played a part; the case study shows an emergent transformation game.

It could be worthwhile to replicate and compare systematically similar cases of threatened energy blackouts. Instead of such an inductive strategy, this case is used as a paradigmatic exemplar (Flyvbjerg 2006). It serves to illustrate and unfold the theoretical argument. Moreover, in line with the ANT sensitivity to social realities that are only in the state of becoming (Latour 2005), the very empirical example demonstrates the fundamental difficulty in deciding whether or not a case displays game-changing. As a recently started process, it is as yet unknown whether the threat will eventually be drawn upon successfully by social innovation actors or will turn out as a welcome crisis situation for incumbent actors to legitimize the normal course of play. The case underlines how game-changers are ultimately only identifiable in retrospect, yet are nevertheless used to make sense of present situations and their potentialities. Three salient aspects of the transformation game will be highlighted, namely, the solidarities involved, the field demarcations at issue, and the recruitment dynamics.

\section{THE BELGIAN ELECTRICITY BLACKOUT THREAT}

In August 2014, the Belgian government announced that the country might be lacking electricity during the upcoming winter of 2014-2015 because of the unexpected closure of three nuclear power plants: Doel 3 and Tihange 2 had been shut down following unexplained anomalies in the reactor vessels, and Doel 4 had been stopped because of an act of sabotage. This nuclear shutdown (3 GW) represents approximately one-quarter of Belgian peak consumption (13 GW). Because Belgium was already at the edge of provision, and because electricity imports are technically limited (3.5 GW) and unreliable (the bordering countries might need their electricity at peak hours), federal authorities had developed an emergency plan by September 2014. Load would be shed for defined parts of the grid at peak hours (SPF Economy 2015), i.e., parts of the electricity grid would be shut down temporarily. Elia, the Belgian transmission system operator, announced on 13 September 2014 that load might be lacking for 49 to $116 \mathrm{~h}$ for the upcoming winter.

As a complementary strategy to the load shedding plan, federal authorities issued a communication plan in November 2014 (Offon, http://offon.be/). The plan specified procedures for warning all institutional and societal players (households, enterprises, industries, and administrations) of upcoming bottlenecks (and shut-downs), and explicitly asked the involved players to reduce their electricity consumption during these key hours of shortage. A collective solidarity-based near-to-real-time demand-management experiment was born, with the intention of avoiding unplugging whole parts of the Belgian electricity grid. How exactly the household, institutional, and economic or industrial players were meant to deal with their unmet electricity demand was largely left to collective creativity. However, alternative and institutional players also turned to investigating social innovation practices as collective, demand-sided means to supersede or complement the (individualistic, supply-sided) acts of buying diesel- or petrol-fueled electricity generators.

Although the load shedding plan was not implemented during winter 2014-2015, because of a relatively mild winter and massive electricity imports from surrounding countries, the processes involved show interesting features of transformation games, and particularly, how they come into being.

\section{Solidarities: learning about linkages}

Nonhumans play a crucial role in the interactions between natural and social systems, which interactions can be characterized as solidarities. The Belgian blackout case clearly illustrates this idea. The apparently precarious electrical grid can be considered as a 
big game involving many players, with nonhuman actors as essential parts of it. Similar to a symbiosis, solidarity empowers each actor that participates in the networked action. In its widest acceptation, the grid solidarity on which the load-shedding plan explicitly relies encompasses not only human players but also the sources of energy production, electrical currents, wires, machines, prices, producers, transmitters, distributors, regulations, and many more actants. This solidarity, and the electricity game itself, is typically not perceived as long as electricity production and consumption are adequately coordinated by machinery, engineering ingenuity, and experience. The electricity game is really an assemblage of players and nonhuman actants in which the different kinds of solidarities can really be revealed only through actual or threatened dysfunction (Bennett 2005).

In the Belgian case, grid solidarity went unnoticed as long as the game continued. However, through a sequence of events, three crucial elements of this apparently self-evident grid solidarity suddenly left the game: the three nuclear plants as sources of power production. This brought to light a whole series of more specific kinds of solidarities. First, the essential technical solidarity became apparent, i.e., the technical grid-defined requirement that production and consumption of electricity are to be tightly balanced at all times, i.e., through a set of automatic and manual devices, the frequency of the grid is maintained within a narrow interval around $50 \mathrm{~Hz}$. From an ANT point of view, that frequency stability is the technical actor that makes the network exist. This technical solidarity is organized so that the grid is acting more or less out of itself, leaving most players with the simple role of consumers. Second, a whole set of other solidarities were publicly revealed through the blackout threat. Economic solidarity, for example, links the reactors, alternative energy sources, producers, and consumers together in an energy market in which prices, subsidies, taxations, and costs, and their modeled developments, were assumed to interact. Third, environmental associations emphasized that ecological solidarities were also in play, arguing that renewable energy sources could be an alternative to nuclear power sources.

In the end, additional solidarities came into view. It became more evident how consuming players were actually strongly associated with each other through their individual dependences on the grid, e.g., as individual consumers (industrial or private), household members, or community members. A typical example was the advice to consumers not to take showers or wash clothes at peak consumption times, and a controversy arose about the importance of charging mobile telephones during peaks. As different kinds and levels of solidarities became visible, it became less evident what the grid and its management comprised and did not comprise. In the end, the emergence of these complementary or conflicting solidarities opened up a process in which the electricity game and its playing field were redefined.

\section{A shifting field}

As long as electricity grids are designed to provide sufficient energy flows from centralized power plants, the game remains largely encapsulated in the maintenance of the technical solidarity. In the 1980s, this unified field definition had been challenged by politics. The liberalization of electricity markets, splitting the competences of production, transmission, and distribution, was a deliberate game-changer endorsed by governments who asserted, and were convinced, that the new game would also be profitable to consumers (Pollitt 2012). Liberalization changed the rules of the game, even recruiting new players, in obliging, for example, consumers to consult tariff lists. The ensuing emphasis on economic solidarities helped to associate electrical flows to trade values as they form on markets every hour. As the hourly electricity price became a main actor on the grid, businesses became connected with customers. Small consumers (e.g., households and small and medium-sized enterprises) have proven difficult to be enrolled in the new game, however (Strengers 2013). Their possible moves remain limited to an incidental change of electricity supplier, and there are few indications of consumers shifting their consumption practices more structurally. Thus, despite the incitement of play intended with the liberalization game-changer, for many the game had hardly begun.

The load shedding plan also ran into the reality of political opposition and distributional tensions within the supposedly unitary playing field. Public debates emerged over the consequences of the programmed prioritizations between different types of players that should, in any case, be kept on the grid (e.g., industries vs. households, rural vs. urban). These tensions and divisions brought forward markedly different delineations of the game. Players advocating political alternatives emphasized the many social and ecological solidarities at play. For them, the field was much larger and systemic than it was portrayed to be by the dominant actors, an indication of a more general governance failure and an opportunity for renewal and experimentation. At the microscale, for instance, citizen associations called for experimental blackout parties, turning the absence of electricity into an opportunity to gather neighbors and develop collective engagement. At the macroscale, a green electricity provider tested the mobilization of 110 voluntary households in asking them via SMS (short message service) to reduce their energy consumption during three hours on a specific day. Likewise, a green consultant initiated a collective experiment through the "first civic and collaborative plan of electricity demand reduction" (Citizens' Reserve: http://www.citizensreserve. be). All were social innovations in the making.

In contrast, the existing economic, technical, and grid solidarities created countervailing forces against the idea of a shifting field. The imagined measures and policies to respond to the blackout threat have been focusing on changing the technical and economic rules. Technically, the objective was to identify districts that could be safely disconnected. Economically, an increase in supplydemand balance fines for electricity providers was implemented. Authorities have prioritized technical fixes and economic instruments also for lack of knowledge about final users' behavioral responses to the communications about scarcity and appeals for reduced energy use. Only a real experiment might have shown how load shedding and blackouts might be circumvented through the recruitment of consumers as players.

\section{Recruitment and activation: becoming a player}

The blackout threat appeared as a promising possible gamechanger to those particular actors who had recognized the problematic state of technical, economic, ecological, and social solidarities beforehand. Unlike most of the actors involved, they had already considered the necessity of changing the rules. More 
generally, the case reveals a mixed picture regarding players' constitutions. Regarding the dominant economic and technical solidarities and the associated delineations of the playing field, many alleged players were hardly aware of any game changing. Finding themselves as players in the game for the first time, for them, the transformation game was either only beginning or just a transient accident.

There is evidence that the blackout threat was interpreted in accordance with the prevalent solidarities. Tellingly, the Federal Plan Bureau communicated that one hour of daytime blackout would cost half of its normal GDP worth (Devogelaer 2014). This kind of calculation reinforces the idea that electricity is vital to the economy and that provision should be ensured by all means. In public debates and forums, some Belgians thus blamed either authorities or producers for their improvidence, confirming the situation in which agency and play are delegated to the producers. Meanwhile, several nonhuman actors were recruited as reliable allies. At the grid level, solutions were sought in increasing production capacities or larger international connectivity. At the individual level, the thriving sale of diesel- or petrol-powered electricity generators displayed not only the vital importance attached to continued provision of electricity, but also revealed a lack of trust in collective solutions. Moreover, load shedding was generally not considered as an interesting collective experiment. Instead, it appeared to many players as something that should and could be avoided through better technological investments and adequate prices. More generally, players remained unsure whether and how others would act in response to the signals of the load-shedding plan. Next to the signals of emerging collective and socially innovative action, there were also the less optimistic suspicions that overly playful free-rider behaviors would arise.

Debates about the load-shedding plan uncovered how very few people understood how the grid works, and which responsibilities and stakeholders are involved. Environmental associations were prompt to enter the game, trying to show that load shedding, in reducing and shifting electricity consumption, could have collective learning effects that are needed to incorporate increases in intermittent sources. The associated environmental solidarities were generally not exhibited, however, because environmental associations preferred to insist on immediate actions (decreasing electricity consumption) rather than on long-term solutions. Changing the game in this case would arguably involve a broader learning process, stimulated through diverse experimentations (Dupuy 2004). Crucially, the techno-economic fixes were premised on the idea that experimentation would be too chancy. These fixes basically confirmed the prevailing rules of the game.

Most of the grid players thus seemed unaware of their game involvement. A majority of consumers realized for the first time that their access to electricity is directly connected to that of other consumers. A kind of solidarity of uses emerged, made apparent through the circumstances. The mere announcement of a possible blackout and the subsequent discussions have changed social representations of the grid, revealing the solidarities in which daily practices are enmeshed, and the shares and stakes in game participation. The grid has gained presence: the television weather forecast has even inserted a daily communiqué regarding the state of the grid.

Opting for eco-power, energy saving, and having an interest to be engaged in energy communities or other socially innovative activities are ways of playing well beyond the traditional roles of passive and individualized consumption. These modes of play have spread beyond the alternative communities. Even more so, some of these socially innovative players seized the blackout threat as an opportunity for arguing that another grid is possible. Microgrids have, for instance, been mobilized as a possible answer to disruptions. Providing local resilience rather than the current grid-defined resilience, they would make the game more sustainable.

The further course of play, and therefore the extent of gamechanging, is fundamentally uncertain. Because the load-shedding plan was not activated during the winter of 2014-2015, it is essentially unknown how players would really have acted. Previous experiences in other countries have proven that alerts of forthcoming threats can temporarily change the game, provided that players receive clear and only incidental alerts to do so (Meier 2005, Pasquier 2011, Strengers 2013). Moreover, the Fukushima disaster and the entailed nuclear power plant closures in Japan have been followed by drastically reduced electricity consumption. Still, the Belgian game has its own history in which solidarities, field demarcations, and dispositions of players have been formed. It is therefore likely to take its own course in times of load shedding. As long as the blackout threat is not perceived as something inherent to an unsustainable socio-technical system, but is rather blamed on specific human players (for example, incompetent engineers or partisan politicians or lobbyists), petrified technical and economic solidarities may even be confirmed. However, the threat does seem to have initiated some game-changing. It did evoke new representations of the grid, impulses toward experimentation and collective solutions, awareness of nontechnical and noneconomic solidarities, and deeper engagements with the associated players. In short, the blackout threat did unleash a degree of social innovation agency into the game. Even if the threat did not materialize into a gamechanging event that helped the social innovation initiatives to achieve substantial transformative changes, its very hypothesis and possibility crucially induced change at the level of the transformation game. It started the game and recruited and activated its players. Or more precisely, the perceived threat showed activation of the players, and the ensuing transformation game, as a realistic possibility.

\section{CONCLUSION: EMERGENT TRANSFORMATION GAMES}

The game-changer term is a metaphor that helps actors to make sense of TSI processes. Considering the apparent persuasiveness and associated performativity of the metaphor, we have critically explored the assumptions it carries about social innovation agency. Invoking insights from actor-centered institutionalism and ANT, we developed a nonreductionist account of transformation games. Through an exploration of the Belgian electricity blackout threat example, the following can be concluded.

A first observation is that the game metaphor is indeed a valuable sense-making device. It does seem to convey some essences of TSI processes that similar notions such as landscape pressures or wildcard events do not achieve through their less immediate and rich imageries. The game metaphor articulates well the alternative courses of play and the alternative rules that social innovation actors seek to promote. It articulates that regime-like societal rules 
are involved, and likewise expresses agonistic elements of TSI processes such as winning and losing: Will others go along in the collective alternative practices of electricity use, or free-ride individually instead? Finally, it expresses some of the voluntarism, creativity, and playfulness that seem characteristic for social innovations as sources of transformation. The initiatives toward blackout parties underlined how TSI players want the game to be meaningful, and fun too.

Still, there are some aspects of TSI that the game metaphor easily obscures and some unwarranted assumptions that it introduces. A second observation is that these transformation games tend to involve coupled social systems, which are structured through players' entwinements with nonhuman players. Many kinds of such solidarities can be at play simultaneously, and they may change over time. The blackout threat case highlighted how technical and economic solidarities tend to dominate play. As the normal course of play was disrupted by the blackout threat, ecological and practical solidarities gained some prominence. Crucially, the very circumstance of solidarities became more apparent to the players. The game metaphor, with its emphasis on play, carries some unwarranted anthropocentrism. This easily weakens human players' sense of the interdependencies involved.

Third, the very reference to the game easily reifies the playing fields that in TSI processes tend to be unclear and contested. It is true that many political games are fought between well-known constellations of actors and institutions and over fairly welldemarcated systems. Still, in TSI games, these very delineations and their stabilities are meant to be at stake. The case highlighted how considerations of not only insiders vs. outsiders and economic vs. environmental values, but also distribution between social groups and regions, led to divergent understandings of what the playing field comprised.

Finally, a particularly salient aspect of the transformation game seems to be the recruitment and activation of its players. The game metaphor introduces an imagery of games in full swing, and of players in the heat of the action suddenly led into a new course of play through game-changers. This imagery has been shown to be somewhat misleading. The threat of blackout did ignite some ambitions toward TSI. Because the blackout was only hypothetical, however, old patterns of play persisted, but there were clear glimpses of other agency and play. Moreover, the blackout threat laid bare the passivity of a significant share of the alleged players, and crucially recruited and activated them into a transformation game that was just emerging.

The observed importance of activation is worthwhile considering for its broader implications. It addresses a paradox of transformative agency that might apply more generally to TSI processes. The electricity blackout example seems not to be the only case in which the systemic rigidities (Scheffer and Westley 2007) in energy production are problematized by social innovation initiatives. Outsider social innovation initiatives typically challenge the earlier delegations of agency onto nonhuman actants and the associated system builders (Chilvers and Longhurst 2016, Smith et al. 2016). Similar TSI activities toward inclusion and activation can be observed beyond the energy system (Jørgensen et al. 2015). Still, the observed activation and recruitment of nonplayers shows a paradoxical trait of TSI agency (see van Oenen 2006, Pel 2016). The rise of social innovation shows dissatisfaction with petrified social structures and the ensuing offside positions of many players. It may also simultaneously demonstrate the difficulty of acting and transforming because of the very passivity of players that has emerged. Particularly in the context of transformation games that have yet to emerge, the performative power of the game-changer metaphor merits that it be taken well into account.

Responses to this article can be read online at: http://www.ecologyandsociety.org/issues/responses. $\mathrm{php} / 8346$

\section{Acknowledgments:}

This article is based on research carried out as part of the Transformative Social Innovation Theory ("TRANSIT") project, funded by the European Union's Seventh Framework Programme (FP7) under grant agreement 613169

\section{LITERATURE CITED}

Avelino, F. 2011. Power in transition: empowering discourses on sustainability transitions. Dissertation. Erasmus University, Rotterdam, The Netherlands. [online] URL: http://hdl.handle. net/1765/30663

Avelino, F., A. Dumitru, N. Longhurst, J. Wittmayer, S. Hielscher, P. Weaver, C. Cipolla, R. Afonso, I. Kunze, J. Dorland, M. Elle, B. Pel, T. Strasser, R. Kemp, and A. Haxeltine. 2015. Transitions towards 'new economies'? A transformative social innovation perspective. TRANSIT Working Paper 3. TRANSIT, Rotterdam, The Netherlands. [online] URL: http://www.transitsocialinnovation. eu/content/original/Book $\% 20$ covers/Local $\% 20$ PDFs/

180\%20TRANSIT_WorkingPaper3 NewEconomy_AvelinoetalSeptember2015.pdf

Axelrod, R., and W. D. Hamilton. 1981. The evolution of cooperation. Science 211(4489):1390-1396. http://dx.doi.org/10.1126/ science. 7466396

Beck, U. 1992. Risk society: towards a new modernity. Sage, London, UK.

Bennett, J. 2005. The agency of assemblages and the North American blackout. Public Culture 17(3):445. http://dx.doi. org/10.1215/08992363-17-3-445

Cajaiba-Santana, G. 2014. Social innovation: moving the field forward. A conceptual framework. Technological Forecasting and Social Change 82:42-51. http://dx.doi.org/10.1016/j.techfore.2013.05.008

Chettiparamb, A. 2006. Metaphors in complexity theory and planning. Planning Theory 5(1):71-91. http://dx.doi. org/10.1177/1473095206061022

Chilvers, J., and N. Longhurst. 2016. Participation in transition (s): reconceiving public engagements in energy transitions as coproduced, emergent and diverse. Journal of Environmental Policy and Planning, in press. http://dx.doi.org/10.1080/1523908X.2015.1110483

Devogelaer, D. 2014. Belgische black-outs berekend een kwantitatieve evaluatie van stroompannes in België. Federaal Planbureau, Brussels, Belgium. 
Dupuy, J. P. 2004. Pour un catastrophisme éclairé. Seuil, Paris, France.

Fabricius, C., C. Folke, G. Cundill, and L. Schultz. 2007. Powerless spectators, coping actors, and adaptive co-managers: a synthesis of the role of communities in ecosystem management. Ecology and Society 12(1):29. [online] URL: http://www.ecologyandsociety. org/vol12/iss1/art29/

Flyvbjerg, B. 2006. Five misunderstandings about case-study research. Qualitative Inquiry 12(2):219-245. http://dx.doi. org/10.1177/1077800405284363

Franz, H.-W., J. Hochgerner, and J. Howaldt. 2012. Challenge social innovation: an introduction. Pages 1-16 in H.-W. Franz, J. Hochgerner, and J. Howaldt, editors. Challenge social innovation: potentials for business, social entrepreneurship, welfare and civil society. Springer, Berlin, Germany. http://dx.doi. org/10.1007/978-3-642-32879-4 1

Geels, F. W. 2014. Regime resistance against low-carbon transitions: introducing politics and power into the multi-level perspective. Theory, Culture and Society 31(5):21-40. http://dx. doi.org/10.1177/0263276414531627

Geels, F., R. Kemp, G. Dudley, and G. Lyons. 2012. Automobility in transition: a socio-technical analysis of sustainable transport. Routledge, New York, New York, USA.

Geels, F. W., and J. Schot. 2007. Typology of sociotechnical transition pathways. Research Policy 36(3):399-417. http://dx.doi. org/10.1016/j.respol.2007.01.003

Grin, J., J. Rotmans, and J. Schot. 2010. Transitions to sustainable development: new directions in the study of long term transformative change. Routledge, New York, New York, USA.

Haxeltine, A., F. Avelino, J. Wittmayer, R. Kemp, P. Weaver, J. Backhaus, and T. O'Riordan 2013. Transformative social innovation: a sustainability transitions perspective on social innovation. NESTA, London, UK. [online] URL: http://kemp. unu-merit.nl/pdf/Haxeltine $\% 20$ et $\% 20$ al. $\% 202013 \% 20$ TSI $\% 20$ Transition $\%$ 20Perspective.pdf

Hess, D. J. 2014. Sustainability transitions: a political coalition perspective. Research Policy 43(2):278-283. http://dx.doi. org/10.1016/j.respol.2013.10.008

Hopkins, R. 2008. The transition handbook. Green Books, Totnes, UK.

Howaldt, J., R. Kopp, and M. Schwarz. 2015. On the theory of social innovations: Tarde's neglected contribution to the development of a sociological innovation theory. Beltz Juventa, Weinheim, Germany. [online] URL: http://nbn-resolving.de/urn: nbn:de:0168-ssoar-419633

Hubert, A. 2010. Empowering people, driving change: social innovation in the European Union. Bureau of European Policy Advisors. Publications Office of the European Union, Luxembourg City, Luxembourg. [online] URL: http://ec.europa. eu/DocsRoom/documents/13402/attachments/1/translations/en/renditions/ pdf

Hughes, T. 1983. Networks of power: electrification in Western society 1880-1930. JHU Press, Baltimore, Maryland, USA.
Jensen, J., M. S. Jørgensen, M. Elle, and E. H. Lauridsen. 2012. Has social sustainability left the building? The recent conceptualization of "sustainability" in Danish buildings. Sustainability: Science, Practice, and Policy 8(1):94-105.

Jessop, B., F. Moulaert, L. Hulgård, and A. Hamdouch. 2013. Social innovation research: a new stage in innovation analysis? Pages 110-130 in F. Moulaert, D. Maccallum, A. Mehmood, and A. Hamdouch, editors. The international handbook on social innovation: collective action, social learning and transdisciplinary research. Edward Elgar, Cheltenham, UK.

Jørgensen, M. S., J. Dorland, B. Pel, and J. Wittmayer. 2015. Characterisation and comparison of case study findings - Batch 1 cases. TRANSIT deliverable 4.2. Transit, Rotterdam, The Netherlands.

Jørgensen, U. 2012. Mapping and navigating transitions - the multi-level perspective compared with arenas of development. Research Policy 41(6):996-1010. http://dx.doi.org/10.1016/j. respol.2012.03.001

Kemp, R., D. Loorbach, and J. Rotmans. 2007. Transition management as a model for managing processes of co-evolution towards sustainable development. International Journal of Sustainable Development and World Ecology 14(1):78-91. http:// dx.doi.org/10.1080/13504500709469709

Klein, N. 2014. Climate change is a people's shock. The Nation September 16, 2014. [online] URL: http://www.thenation.com/ article/181621/climate-change-peoples-shock

Koppenjan, J. F. M., and E. H. Klijn. 2004. Managing uncertainties in networks: a network approach to problem solving and decision making. Routledge, New York, New York, USA.

Latour, B. 1992. Where are the missing masses? The sociology of a few mundane artifacts. Pages 225-258 in W. Bijker and J. Law, editors. Shaping technology/building society: studies in sociotechnical change. MIT Press, Cambridge, Massachusetts, USA.

Latour, B. 2004. Why has critique run out of steam? From matters of fact to matters of concern. Critical Inquiry 30(2):225-248. http://dx.doi.org/10.1086/421123

Latour, B. 2005. Reassembling the social: an introduction to actornetwork theory. Oxford University Press, Oxford, UK.

Law, J. 2006. Disaster in agriculture: or foot and mouth mobilities. Environment and Planning A 38(2):227-239. http://dx.doi. org/10.1068/a37273

Law, J., and J. Hassard. 1999. Actor network theory and after. Wiley-Blackwell, Oxford, UK.

Meier, A. 2005. Saving electricity in a hurry: dealing with temporary shortfalls in electricity supplies. Organisation for Economic Co-operation and Development and International Energy Agency, Paris, France. [online] URL: https://www.iea.org/ publications/freepublications/publication/savingelec.pdf

Moore, M.-L., O. Tjornbo, E. Enfors, C. Knapp, J. Hodbod, J. A. Baggio, A. Norström, P. Olsson, and D. Biggs. 2014. Studying the complexity of change: toward an analytical framework for understanding deliberate social-ecological transformations. 
Ecology and Society 19(4):54. http://dx.doi.org/10.5751/ es-06966-190454

Moore, M.-L., and F. Westley. 2011. Surmountable chasms: networks and social innovation for resilient systems. Ecology and Society 16(1):5. [online] URL: http://www.ecologyandsociety. org/vol16/iss 1/art5

Moore, M.-L., F. R. Westley, O. Tjornbo, and C. Holroyd. 2012. The loop, the lens, and the lesson: using resilience theory to examine public policy and social innovation. Pages 89-113 in A. Nicholls and A. Murdock, editors. Social innovation: blurring boundaries to reconfigure markets. Palgrave Macmillan, Basingstoke, UK. http://dx.doi.org/10.1057/9780230367098.0010

Moulaert, F., D. Maccallum, A. Mehmood, and A. Hamdouch, editors. 2013. The international handbook on social innovation: collective action, social learning and transdisciplinary research. Edward Elgar, Cheltenham, UK.

Mulgan, G., S. Tucker, R. Ali, and B. Sanders. 2007. Social innovation: what it is, why it matters and how it can be accelerated. Saïd Business School, University of Oxford, Oxford, UK. [online] URL: http://eureka.sbs.ox.ac.uk/761/1/Social_Innovation.pdf

Nicholls, A., and A. Murdock, editors. 2012. Social innovation: blurring boundaries to reconfigure markets. Palgrave Macmillan, Basingstoke, UK.

Pasquier, S. B. 2011. Saving electricity in a hurry: update 2011. International Energy Agency, Paris, France. [online] URL: https://www.iea.org/publications/freepublications/publication/ Saving_Electricity.pdf

Pel, B. 2016. Interactive metal fatigue: a conceptual contribution to social critique in mobilities research. Mobilities, in press. http:// dx.doi.org/10.1080/17450101.2014.942101

Pel, B., and T. Bauler. 2014. The institutionalization of social innovation: between transformation and capture. TRANSIT Working Paper 2. TRANSIT, Rotterdam, The Netherlands. [online] URL: http://www.transitsocialinnovation.eu/content/ original $/ \mathrm{Book}^{2} 20 \mathrm{covers/}$

Local $\% 20$ PDFs/179\%20TRANSIT_WorkingPaper2_Governance Pel141015.pdf

Pollitt, M. G. 2012. The role of policy in energy transitions: lessons from the energy liberalisation era. Energy Policy 50:128-137. http://dx.doi.org/10.1016/j.enpol.2012.03.004

Rammert, W. 2010. Die innovationen der gesellschaft. Pages 21-51 in J. Howaldt and H. Jacobsen, editors. Soziale innovation: auf dem Weg zu einem postindustriellen Innovationsparadigma. VS Verlag für Sozialwissenschaften, Wiesbaden, Germany. http://dx. doi.org/10.1007/978-3-531-92469-4_2

Rip, A. 2006. A co-evolutionary approach to reflexive governance-and its ironies. Pages 82-100 in J. P. Voß and D. Bauknecht, editors. Reflexive governance for sustainable development. Edward Elgar, Cheltenham, UK.

Scharpf, F. W. 1997. Games real actors play: actor-centered institutionalism in policy research. Westview Press, Boulder, Colorado, USA.
Scheffer, M., and F. R. Westley. 2007. The evolutionary basis of rigidity: locks in cells, minds, and society. Ecology and Society 12 (2):36. [online] URL: http://www.ecologyandsociety.org/vol12/ iss $2 / \operatorname{art} 36 /$

Schubert, C. 2014. Social innovations. Highly reflexive and multireferential phenomena of today's innovation society? A report on analytical concepts and a social science initiative. Technology Studies Working Papers TUTS-WP-2-2014. Technical University Berlin, Berlin, Germany. [online] URL: http://nbn-resolving.de/ urn:nbn:de:0168-ssoar-385848

Scott-Cato, M., and J. Hillier. 2010. How could we study climaterelated social innovation? Applying Deleuzean philosophy to Transition Towns. Environmental Politics 19(6):869-887. http:// dx.doi.org/10.1080/09644016.2010.518677

Seyfang, G., and N. Longhurst. 2013. Desperately seeking niches: grassroots innovations and niche development in the community currency field. Global Environmental Change 23(5):881-891. http://dx.doi.org/10.1016/j.gloenvcha.2013.02.007

Sheller, M. 2012. The emergence of new cultures of mobility: stability, openings and prospects. Pages 180-202 in F. Geels, R. Kemp, G. Dudley, and G. Lyons. Automobility in transition: a socio-technical analysis of sustainable transport. Routledge, New York, New York, USA.

Smith, A., T. Hargreaves, S. Hielscher, M. Martiskainen, and G. Seyfang. 2016. Making the most of community energies: three perspectives on grassroots innovation. Environment and Planning A, in press. http://dx.doi.org/10.1177/0308518X15597908

Smith, A., and A. Stirling. 2010. The politics of social-ecological resilience and sustainable socio-technical transitions. Ecology and Society 15(1):11. [online] URL: http://www.ecologyandsociety. org/vol15/iss1/art11/

SPF Economy. 2015. Plan de délestage en cas de pénurie d'électricité. SPF Economie, Brussels, Belgium. [online] URL: http://economie.fgov.be/fr/penurie electricite/plan-delestage/

Stirling, A. 2011. Pluralising progress: from integrative transitions to transformative diversity. Environmental Innovation and Societal Transitions 1(1):82-88. http://dx.doi.org/10.1016/j.eist.2011.03.005

Strengers, Y. 2013. Smart energy technologies in everyday life: smart utopia? Palgrave Macmillan, New York, New York, USA. http://dx.doi.org/10.1057/9781137267054

Summerton, J. 1994. Changing large technical systems. Westview Press, Boulder, Colorado, USA.

Swyngedouw, E. 2005. Governance innovation and the citizen: the Janus face of governance-beyond-the-State. Urban Studies 42 (11):1991-2006. http://dx.doi.org/10.1080/00420980500279869

Tyfield, D., J. Jin, and T. Rooker. 2010. Game-changing China: lessons from China about disruptive low carbon innovation. NESTA, London, UK. [online] URL: http://eprints.lancs.ac. uk/40880/1/Game-Changing-China-v6.pdf

Unger, R. M. 1987. Falsenecessity: anti-necessitarian social theory in the service of radical democracy. Cambridge University Press, Cambridge, UK. 
Van Oenen, G. 2006. A machine that would go of itself: interpassivity and its impact on political life. Theory and Event 9 (2):1-26. http://dx.doi.org/10.1353/tae.2006.0030

Verbong, G., and D. Loorbach, editors. 2012. Governing the energy transition: reality, illusion or necessity? Routledge, New York, New York, USA.

Verhees, B. 2012. Cultural legitimacy and innovation journeys: a new perspective applied to Dutch and British nuclear power. Dissertation. Eindhoven University of Technology, Eindhoven, The Netherlands.

Wallenborn, G. 2016. Designing blackouts. In K. Krois and M. Alvise, editors. By design or by disaster. Bozen University Press, Bozen, Italy, in press.

Wallenborn, G., and G. Gaye. 2015. A typology of flexible users in a smart grid project. Pages 2027-2038 in Proceedings of the ECEEE Summer Study on energy efficiency: first fuel now. European Council for an Energy Efficient Economy, Stockholm, Sweden. [online] URL: http://proceedings.eceee.org/vispanel. php? event $=5$

Walker, B., C. S. Holling, S. R. Carpenter, and A. Kinzig. 2004. Resilience, adaptability, and transformability in social-ecological systems. Ecology and Society 9(2):5. [online] URL: http://www. ecologyandsociety.org/vo19/iss2/art5/

Walsh, C. L., S. Glendinning, V. Castán-Broto, E. Dewberry, and M. Powell. 2015. Are wildcard events on infrastructure systems opportunities for transformational change? Futures 67:1-10. http://dx.doi.org/10.1016/j.futures.2015.01.005

Wittmayer, J. M., J. Backhaus, F. Avelino, B. Pel, T. Strasser, and I. Kunze. 2015. Narratives of change: how social innovation initiatives engage with their transformative ambitions. TRANSIT Working Paper 4. TRANSIT, Rotterdam, The Netherlands. [online] URL: http://www.transitsocialinnovation.eu/content/ original/Book $\% 20$ covers/Local $\% 20 \mathrm{PDFs} / 181 \% 20$

TRANSIT_WorkingPaper 4 Narratives $\% 20$ of $\% 20$ Change_Wittmayer $\%$ 20et $\% 20$ al October2015 2.pdf

Yin, R. K. 2003. Case study research: design and methods. Third edition. Sage, Thousand Oaks, California, USA. 